sera from some leukaemic patients do neutralize growth of mycoplasma first isolated by Negroni, though the inhibitor has not been shown to be antibody, and these results do not solve the problem of the role of this mycoplasma in aetiology of leukaemia, but they make it more likely that it, or an antigenically related organism, does infect man.

Our thanks are due to Dr. R. J. C. Harris, who aranged for the tests and coded the samples. -We are, etc.,

A. J. Beale.

G. J. Christofinis.

Glaxo Laboratories Ltd.

Sefton Park, Stoke Poges, Bucks.

\section{G. NEgRONI.}

Imperial Cancer Research Fund,

Burtonhole Lane.
London N.W.7.

\section{REFERENCES}

I Negroni, G., Brit. med. 7., 1964, 1, 927.

Grist, N. R., and Pallon,'R. J., Brit. med. f.

- Girardi, A. J., Hayflick, L., Lewis, A. M., and Somerson, N. L., Nature (Lond.), 1965, 205,

- Negroni, G., Proc. roy. Soc. Med., 1966, 59, 662 Proceedings of a Symposium, 1967, p. 91 Baltimore.

- Grist, N. R., Brit. med. F., 1966, 2, 1135. Fallon, R. J., (Abstract) Proceedings Society General Microbiologists fanuary Meeting, 1967 p. 5. London.

D. C., and Chanock, R. M., f. Hyg., (Lond.),

Fallon, R. 'J., Vet Rec., 1966, 79, 700.

\section{St. Wolfgang and Gout}

SIR,-I enjoyed the Christmas Quiz (23 December, p. 740), but have a question concerning the listing of St. Wolfgang as patron saint of sufferers from gout. Investigating this matter some years ago, we found no fewer than a dozen saints and holy persons who were credited with cures of the gout. ${ }^{1}$ These include Andrew the Apostle, St. Julian of Alexandria, St. Sebastian, St. Tranquillanus, Bl. Autriclinian of Limoges, St. Maurice, St. Placidus, St. Maurus, St. Stapinus of Dourgne, St. Gallus, Hildegard of Bingen, and St. Albert of Messina. Somehow we missed St. Wolfgang, however, and would appreciate more information concerning his dates and activities. - I am, etc.,

GERALD P. RodNAN

\author{
Department of Medicine, \\ niversity of Pittsburgh \\ Pittsburgh, Pennsylvania, U.S.A.
}

REFERENCB Rodnan, G. P., and Benedek, T. G., Arthr. and
Rheum., 1963, 6, 317.

\section{Hospital Attachments}

SiR,-Last November all items of work in my practice were noted, as had already been done during two previous Novembers. ${ }^{32}$ No great difference from the figures of two years ago appeared, but on further investigation it turned out that much of the routine work in the practice could equally well have been performed by a district nurse or health visitor. One hundred and twenty-one visits, or about a quarter of the 441 home visits made in the month, could have been dealt with in this way. The general practitioner could there- fore be freed to make fuller use of his special skills, but how can he achieve this in the present state of evolution of our health services?

One way would be to allow general practitioners to have access to hospital beds as described in your General Practice Observed article (17 February, p. 436). Should the general practitioner be able to follow into hospital selected cases within the scope of his professional skill, several advantages immediately follow.

The practitioner is enabled to make full use of his knowledge, and is not, because of the rigid barrier between hospital and general practice, debarred from this.

The hospital medical staff would be relieved of a good deal of the routine work and would be able to devote more time to the more difficult and complicated cases.

The removal of some of the routine work of the hospital would lessen the present strain on and difficulty in obtaining, junior hospital staff.

The increased contact with the hospital would be of inestimable benefit to the general practitioner and perhaps also to the hospital staff.

The problem is how to bring about this desirable state of affairs when the integration of such patients into the traditional hospital ward presents so many difficulties. Could not facilities be provided in district hospitals such as are enjoyed by our colleagues who have access to cottage hospitals, and a male and female ward set aside for such a purpose in each new district hospital ? These wards would be run entirely by general prac titioners, who would provide a 24-hour-day cover for their patients. The resident hospital staff would have no duties in connexion with the unit, though the consultant staff would be available for consultation. The administration of these wards would be by the hospital secretary and matron, while the laboratory and diagnostic facilities would be as at present, available for use by the general practitioners.

A difficult scheme to work, you may say, but those general practitioners and their patients who use the facilities of a cottage hospital can point out with justification that these units, where they already exist, function to the benefit of all, and the rigid barriers between the hospital doctor and the general practitioner are lowered.-I am, etc.,

Lockerbie,

JOHN WILSON.

Dumfriesshire.

REFERENCES

1 Wilson, J. B., Lancet, 1964, 2, 467.
2 Wilson, J. B., Lancet, 1966, 1, 144.

\section{Trainee Anaesthetists}

SIR,-The Associates in Training Com mittee of the Association of Anaesthetists of Great Britain and Ireland represents the views of trainee anaesthetists to the Counci of the Association of Anaesthetists.

I would draw attention to the Ministry of Health Memoranda H.M.(67) 26 or S.H.M 30/1967 (Minimum Time Off-duty for Junior and Intermediate Grades of Hospital Medical and Dental Staff) and H.M.(67)27 or S.H.M. 29/1967 (Professional and Study Leave for Medical and Dental Staff in the Hospital Service). The committee would like to hear from any trainee anaesthetist (up to and including the grade of senior registrar) who has found that the recommenda tions in these memoranda are not being implemented.-I am, etc.,

Alastair A. Spence,

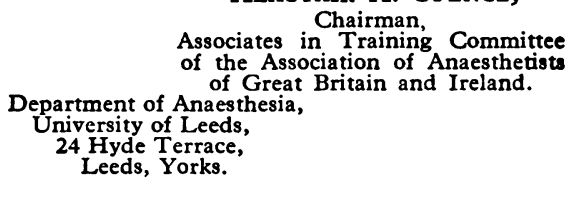

\section{St. Marylebone Division}

SIR,-The St. Marylebone Division of the B.M.A. has been bereaved recently by the loss of Dr. E. C. Warner (obituary, 20 January, p. 187), Miss Gladys Sandes (obituary, 27 January, p. 255), and Dr. D. C. Norris (obituary, 3 February, p. 322). They were all senior members of the Division who had devoted much of their time over the years to the services of the Division and its members, and to the British Medical Association itself.

Dr. Warner was a courteous and able chairman at a time when the Division was passing through a rather difficult phase. Miss Sandes had also been its chairman and was, prior to her death, still an active member of the executive. Dr. Norris had been treasurer for many years.

The Executive of the Division wish to place on record their sincere appreciation of these three colleagues, and of their devoted help and work during their lifetime, and to extend deep sympathy to their families.-We are, etc.,

W.A. H. Stevenson, H. E. A. Carson.

P. Paton-Philip,

E. HOROWITZ.

P. L. BACHus,

Treasurer.

J. HUNT

MAURICE LEe.

R. Cove-SMITH.

London $W .1$.

E. D. PAGe.

A. DICKSON WRIGHT

\section{Points from Letters}

\section{Royal Malady}

Mr. W. B. McKelvie, Ch.M., F.R.C.S.Ed (Isle of Man) writes: In your leading article entitled "Royal Malady" (6 January, p. 2) you mention that it would be worth while seeking evidence of porphyria in the Old Pretender and his offspring, which, if it occurred, would dispose of the story of substitution at his birth.

One trouble James II had in common with his grandson, Prince Charles Edward, was epistaxis. The former was severely affected by nose bleeding during the Boyne campaign, and Prince Charles Edward was similarly troubled during his West Highland wanderings after Culloden. I have not been able to find out whether the old Pretender, or the many descendants of Charles II, suffered from epistaxis.

\section{Dangers of Birth-control Pill}

Dr GuY BOUSFIELD (Broadbridge Heath Sussex) writes: The pill will not kill the gonococcus or the dreaded $T$. pallidum of syphilis. The more primitive, but safer, sheath at least afforded some protection against these and other infections. People with free ideas on sexual intercourse, whether they rely on the pill or not as a contraceptive, are very likely to contract venereal disease and communicate it to their existing paramour. Shall we ultimately be faced with a resurgence of venereal disease? 